\title{
KARAKTERISTIK DAN FENOMENA KEMISKINAN KELUARGA MISKIN PEDESAAN DI ACEH
}

\author{
Arfriani Maifizar \\ Dosen Jurusan Sosiologi Universitas Teuku Umar
}

\begin{abstract}
Abstrak
Kemiskinan merupakan suatu permasalahan sosial masa kini, karena masyarakat sangat sulit keluar dari kondisi kemiskinan yang terjadi. Hal ini disebabkan oleh kehidupan masyarakat hanya cukup untuk memenuhi kebuhan konsumtif rumah tangga, sehingga penghasilan yang diperoleh tidak mampu untuk melakukan ivestasi dalam dunia pendidikan maupun dunia usaha. Lebih menarik perhatian Aceh pasca tsunami, sebahagian kecil masyarakat pesisir yang desanya tidak layak untuk dijadikan pemukiman penduduk maka direlokasikan ketempat yang baru, sehingga dari tempat yang baru tersebut masyarakat sulit beradap tasi karena kondisi alam yang tidak potensial dalam mengembangkan ekonomi rumah tangga. Akibat fenomena tersebut mayoritas para suami bekerja keluar, ada yang menjadi nelayan, petani dan juga ada yang menjadi buruh, sedangkan kaum ibu hanya menjadi menjadi ibu rumah tangga yang tidak produktif. Para ibu rumah tangga hanya duduk dirumah dengan tidak ada pekerjaan karena pengangguran yang dihadapinya. Penganguran ini terjadi karena tidak memiliki skill dalam bidang tertentu, hanya mengharapkan dari hasil kelautan dan penangkapan ikan di sungai. Sayangnya kemiskinan juga terjadi pada kaum lansia yang tidak memiliki keluarga yang produktif, dimana lansia tersebut walaupun akses transportasi yang jauh tetap mencari nafkah kesungai untuk mempertahankan hidup.Karakteristik kemiskinan ini di perparah dengan program pemerintah yang tidak tepat sasaran dalam memberdayakan keluarga miskin. Penelitian ini dilakukan pada masyarakat Gampong Cot Kumbang dan Gampong Suak ie beuso, pendekatan penelitian yaitu menggunakan metodelogi kualitatif, teknik penarikan sampel yaitu purposive sampling. Adapun hasil penelitian yaitu Jauhnya akses ekonomi masyarakat, kegagalan pemberdayaan masyarakat oleh Pemerintah dan LSM dan ketergantungan yang berlebihan masyarakat kepada Pemerintah.
\end{abstract}

Keywords: Kemiskinan, Keluarga, Desa, Ekonomi Lemah, Faktor Kemiskinan 


\section{PENDAHULUAN}

Kesejahteraan sosial merupakan bagian integral dari pembangunan nasional, karena itu, Sasaran pembangunan kesejahteraan sosial adalah Penyandang Masalah Kesejahteraan Sosial (PMKS). Penyandang masalah kesejahteraan sosial menurut Pusat Data dan Informasi Kesejahteraan Sosial (2008) meliputi anak balita terlantar, anak terlantar, anak nakal, anak jalanan, wanita rawan sosial ekonomi, korban tindak kekerasan, lanjut usia terlantar, penyandang cacat, tuna susila, pengemis, gelandangan, bekas warga binaan lembaga kemasyarakatan, korban penyalahgunaan NAPZA, keluarga berumah tidak layak huni, keluarga bermasalah psikologis, komunitas adat terpencil, korban bencana alam, korban bencana sosial atau pengungsi,, pekerja migran terlantar, orang dengan HIV/AIDS (ODHA), keluarga rentan dan keluarga fakir miskin.

Kemiskinan sebagai akar masalah dari permasalahan kesejahteraan sosial lainnya, karenanya rumah tangga sebagai unit terkecil masyarakat dapat menjadi ujung tombak ekonomi, yang diharapkan dapat berkembang pada keluarga yang lebih besar (kerabat) hingga pembentukan perkumpulan yang bersifat ekonomi lainnya. Sebaliknya, bila keluarga miskin tidak segera ditangani maka ia akan makin terpuruk, tidak mempunyai aset untuk produksi, tidak mempunyai keterampilan dan cenderung menjadi pasrah. Rumah tangga miskin seperti ini sangat rapuh dan makin terpuruk apabila kepala keluarga pencari nafkah meninggal, sakit, terkena pemutusan hubungan kerja, terkena bencana alam dan atau konflik sosial lainnya. Keluarga miskin tidak mempunyai kemampuan menghadapi resikoresiko di atas, karena pada umumnya masyarakat/ keluarga miskin tidak mempunyai investasi atau aset. Sedangkan potensi dan sumber kesejahteraan sosial seperti organisasi sosial lokal, kearifan lokal, modal sosial dan potensi alam yang bernilai ekonomis di sekitar lingkungan tempat tinggal masyarakat belum dimanfaatkan secara optimal.

Modal sosial masyarakat Indonesia cukup beragam dan dapat dijadikan pilihan atau alternatif dalam penanganan permasalahan kesejahteraan sosial khususnya keluarga miskin di pedesaan. Putnam (2000) menunjukkan bukti bahwa pertumbuhan ekonomi sangat berkorelasi dengan kehadiran modal sosial. Pertumbuhan ekonomi suatu masyarakat akan baik apabila ciri-ciri berikut ini dimiliki oleh masyarakat: (1) hadirnya hubungan yang erat antar anggota masyarakatnya dan (2) adanya para pemimpin yang jujur dan egaliter yang memperlakukan dirinya sebagai bagian dari masyarakat bukan sebagai penguasa. Ada saling percaya dan kerjasama di antara unsur masyarakat.

Dalam penanganan kemiskinan di pedesaan, organisasi sosial lokal, modal sosial dan kearifan lokal menjadi aspek penting. Dengan 
menumbuhkan, menggerakkan potensi dan sumber-sumber yang ada di masyarakat desa, maka akan tumbuh kemandirian masyarakat dalam penanganan masalah kesejahteraan sosial di pedesaan.

Karakteristik masyarakat yang berada di kawasan pesisir juga menghadapi berbagai pemasalahan yang menyebabkan kemiskinan. Febrianto \& Rahardjo, (2005) menjelaskan pada umumnya mereka menggantungkan hidupnya dari pemanfaatan sumber daya laut dan pantai yang membutuhkan investasi besar dan sangat bergantung musim. Sebagian besar dari mereka bekerja sebagai nelayan kecil hanya mampu memanfaatkan sumberdaya di daerah pesisir dengan hasil tangkapan yang cenderung terus menurun akibat persaingan dengan kapal besar dan penurunan mutu sumber daya pantai. Hasil tangkapan juga mudah rusak sehingga melemahkan posisi tawar mereka dalam transaksi penjualan. Selain itu pola hubungan eksploitatif antara pemilik modal dengan buruh dan nelayan, serta usaha nelayan yang bersifat musiman dan tidak menentu menyebabkan masyarakat miskin dikawasan pesisir cenderung sulit untuk keluar dari jeratan kemiskinan belitan utang pedagang atau pemilik kapal. Secara sosio-kultural masyarakat pesisir merupakan suatu kelompok masyarakat yang akal budayanya pada mulanya dibangun atas panduan antara budaya maritime laut, pantai dan berorientasi pantai. Perbedaan mendasar masyarakat pesisir dan masyarakat agraris adalah pada akses terhadap sumberdaya. Sangat berbeda dengan sumberdaya lahan pada masyarakat agraris, laut merupakan sumber daya alam open acces sehingga siapapun dapat mengaksesnya. Sumber daya yang bersifat terbuka ini menyebabkan persaingan antar nelayan menjadi semakin keras. Tidak meherankan jika nelayan atau penduduk pesisir pada umumnya memiliki karakter yang keras. Terlebih risiko pekerjaan yang tinggi baik dalam keselamatan jiwa maupun ekonomi

Untuk mengetahui secara lebih mendalam tentang potensi dan sumber yang dapat digali dan dikembangkan agar masyarakat mau berpartisipasi aktif dalam pemberian pelayanan sosial kepada masyarakat atau individu yang kurang beruntung, khususnya kepada keluarga miskin, dipandang perlu mengadakan penelitian secara mendalam mengenai faktorfaktor yang berhubungan dengan fenomena dan karakteristik keluarga miskin pedesaan Kabupaten Aceh Barat Provinsi Aceh). Diharapkan dari hasil penelitian ini dapat disusun strategi meningkatkan keberdayaan keluarga miskin pedesaan di Kabupaten Aceh Barat.

Berdasarkan latar belakang permasalahan sosial keluarga miskin di pedesaan Kabupaten Aceh Barat di atas, maka dirumuskan masalah penelitian sebagai berikut:

1. Apa faktor penyebab keluarga miskin di pedesaan?

2. Bagaimana hubungan karakteristik dan ciri keluarga miskin, modal sosial, kearifan lokal, intervensi ekternal dan internal dengan keberdayaan keluarga miskin? 


\section{TINJAUAN PUSTAKA}

\section{Kerangka Pemikiran}

Kemiskinan adalah suatu kondisi ketidakmampuan seseorang, keluarga, kelompok, masyarakat untuk memenuhi kebutuhan fisik (pangan, sandang, papan) dan non-fisik (kesehatan, pendidikan dan rasa aman). Penanganan kemiskinan tidak mungkin hanya ditangani oleh pemerintah, tetapi juga perlu melibatkan masyarakat dan pihak swasta termasuk dunia usaha. Permasalahan kemiskinan adalah menyangkut kegagalan pemenuhan hak-hak dasar seperti terbatasnya kecukupan dan mutu pangan, terbatasnya akses dan rendahnya mutu pelayanan kesehatan, terbatasnya akses dan mutu layanan pendidikan, terbatasnya kesempatan kerja dan berusaha, terbatasnya akses layanan perumahan, terbatasnya akses air bersih, sanitasi dan rasa aman, lemahnya kepastian penguasaan dan pemilikan tanah dan lemahnya partisipasi masyarakat. Di samping itu, kemiskinan disebabkan lemahnya penanganan masalah kependudukan, ketidaksetaraan dan ketidakadilan gender, kesenjangan antar daerah dan lain-lain.

Untuk mengatasi kemiskinan tersebut diperlukan kemampuan pemerintah untuk membangun kerjasama dengan pihak swasta dalam hal ini pihak dunia usaha, masyarakat dan negara lain yang telah berhasil dalam upaya penanganan kemiskinan, sehingga hak-hak dasar seperti tersebut di atas dapat terpenuhi. Sesuatu yang tidak kalah penting dalam penanganan kemiskinan adalah memperluas partisipasi masyarakat, sehingga modal sosial dan kearifan lokal masyarakat mampu menyokong penanganan kemiskinan. Kemiskinan keluarga ditandai oleh ciri sosial ekonomi, ciri fisik, ciri psikologis dan ciri sosiologis.

Kemiskinan pada hakekatnya tidak lepas dari kebodohan atau keterbelakangan suatu komunitas, baik di bidang pendidikan maupun kondisi sosial budaya masyarakat. Hal ini berarti bahwa, bila penanganan kemiskinan hanya dipusatkan pada satu aspek saja, maka hasilnya tidak akan memuaskan. Misalnya penanggulangan kemiskinan yang hanya difokuskan pada bidang pendidikan, atau dengan cara memberikan dana yang melimpah, tidak akan menghasilkan output yang optimal. Oleh karena itu, pendekatan penanganan kemiskinan hendaknya dilaksanakan secara interdisipliner yaitu menyangkut bagaimana mengadakan perubahan sikap, peningkatan pengetahuan dan peningkatan keterampilan individu, kelompok maupun masyarakat. Masyarakat pedesaan di Indonesia sebagian besar mempunyai mata pencaharian bertani dengan kepemilikan lahan pertanian yang sangat terbatas. Di pandang dari aspek sosial ekonomi kepemilikan lahan pertanian yang terbatas ini, tidak memungkinkan petani mampu melepaskan diri dari kondisi kemiskinan tanpa modernisasi pertanian. Menurut Sajogyo (1991), perkembangan pertanian yang maju dan 
berkelanjutan (sustainable) memerlukan dukungan: (1) melalui riset dan pengembangan teknologi untuk meningkatkan produktivitas pertanian secara efisien dan berlanjut, sampai teknologi baru tersebut terjangkau oleh petani lahan sempit dan bermodal terbatas, (2) pengembangan kelembagaan yang mampu mendukung masyarakat petani dan desa dalam menyebarkan dan mengembangkan teknologi baru, termasuk penyediaan informasi dan pemecahan masalah di tingkat wilayah pelayanan, (3) pengembangan sumberdaya manusia yang diperlukan dalam bentuk pelatihan keterampilan dan mendorong semangat kerjasama kelompok dan (4) pertumbuhan dan pelestarian barang modal, misalnya material, bibit unggul dan sumber plasma nutfah yang tetap terjangkau.

Subyek penelitian ini adalah keluarga miskin di Gampong Cot Kumbang dan Suak Ie Beuso Kabupaten Aceh Barat Provinsi Aceh. Dipilihnya permasalahan sosial keluarga miskin menjadi subyek penelitian, terkait dengan keberadaan keluarga miskin di pedesaan secara kuantitas jumlahnya cukup besar dibandingkan dengan di perkotaan (BAPPEDA Aceh, 2013).

Terkait dengan hal di atas, penelitian didesain kualitatif. Pemahaman yang mendalam terhadap suatu fenomena sosial adalah yang penting. Irawan (2002) menyatakan bahwa penelitian kualitatif adalah penelitian untuk memahami makna (means) yang berada dibalik fakta-fakta.

Penelitian kualitatif bertujuan menjelaskan sesuatu apa adanya, yang memungkinkan peneliti memilih satu obyek penelitian untuk dikaji secara mendalam. Hasil penelitian dengan menggunakan metode ini diharapkan dapat memberikan gambaran sesuai dengan kondisi yang nyata di lapangan. penelitian hendak menguji hubungan karakteristik keluarga miskin, wilayah, modal sosial, kearifan lokal, intervensi pemerintah maupun organisasi sosial/lembaga swadaya masyarakat dalam penanganan keluarga miskin dan ciri -ciri keluarga miskin (ciri sosial ekonomi, fisik, psikologi, sosiologi) hubungannya dengan keberdayaan keluarga miskin pedesaan.

Pendekatan analisis data kualitatif digunakan untuk mengembangkan pemahaman yang mendalam tentang permasalahan penelitian yang digali diantara informan atau subyek penelitian. Melalui pendekatan ini diharapkan dapat menggambarkan kompleksitas permasalahan sosial dan untuk menghindari keterbatasan pemahamanan atas suatu teori tertentu. Melalui pendekatan analisis data kualitatif, diungkap realita sosial secara menyeluruh atau komprehensif dan mendalam tentang permasalahan penelitian. Diharapkan dengan menggunakan kaidah kualitatif, dapat lebih mudah memahami permasalahan penelitian secara mendalam.

\section{Pengumpulan data}

Pengumpulan data juga dilakukan dengan teknik wawancara mendalam (indepth interview) yang digunakan untuk menggali lebih dalam informasi, sehingga lebih memahami kondisi tingkat partisipasi masyarakat 
berikut hambatan dan kemudahannya. Penggunaan berbagai teknik pengumpulan data dan teknik pencatatan dilakukan untuk menjamin hasil penelitian yang netral, yang lebih menggambarkan keadaan sesungguhnya dan lebih menjamin kebenaran data. Berdasarkan hal tersebut di atas maka teknik pengumpulan data yang dipergunakan dalam penelitian ini adalah sebagai berikut:

Tabel 1. Sumber data dan teknik pengumpulan data

\begin{tabular}{|c|c|c|c|}
\hline No & $\begin{array}{c}\text { Data dan Informasi yang } \\
\text { ingin diperoleh }\end{array}$ & Sumber data/informasi & $\begin{array}{c}\text { Teknik } \\
\text { Pengumpulan Data }\end{array}$ \\
\hline 1 & $\begin{array}{l}\text { Peraturan daerah yg terkait } \\
\text { pemberdayaan kk miskin }\end{array}$ & $\begin{array}{l}\text { Pemda Kabupaten Aceh } \\
\text { Barat }\end{array}$ & Studi dokumentasi \\
\hline 2 & $\begin{array}{l}\text { Gambaran karakteristik } \\
\text { wilayah dan kependudukan } \\
\text { lokasi penelitian }\end{array}$ & Aparat kecamatan, desa & Studi dokumentasi \\
\hline 3 & $\begin{array}{l}\text { Hasil penelitian terkait } \\
\text { penanganan kk miskin }\end{array}$ & Perpustakaan & Studi dokumentasi \\
\hline 4 & Kepercayaan sosial (trust) & Masyarakat kk miskin & Deep Interview \\
\hline 5 & Hubungan timbal balik & $\begin{array}{l}\text { Tokoh adat, tokoh } \\
\text { pemuda, agama, wanita, } \\
\text { LSM, kk miskin }\end{array}$ & Deep Interview \\
\hline 6 & $\begin{array}{l}\text { Sikap terhadap penanganan } \\
\text { keluarga miskin }\end{array}$ & $\begin{array}{l}\text { Tokoh adat, tokoh } \\
\text { pemuda, agama, wanita, } \\
\text { LSM, kk miskin }\end{array}$ & $\begin{array}{l}\text { Deep Interview } \\
\text { Deep Interview }\end{array}$ \\
\hline 7 & $\begin{array}{l}\text { Pengetahuan masyarakat } \\
\text { terhadap keluarga miskin }\end{array}$ & $\begin{array}{l}\text { Tokoh adat, tokoh } \\
\text { pemuda,agama, wanit, } \\
\text { LSM, kk miskin }\end{array}$ & Deep Interview \\
\hline 8 & $\begin{array}{l}\text { Keterampilan menggali } \\
\text { dan mengembangkan } \\
\text { sumber terkait persoalan kk } \\
\text { miskin }\end{array}$ & $\begin{array}{l}\text { Tokoh adat, tokoh } \\
\text { pemuda, agama, wanita, } \\
\text { LSM, kk miskin }\end{array}$ & Deep Interview \\
\hline 9 & $\begin{array}{l}\text { Pola penanganan keluarga } \\
\text { miskin oleh kerabat, } \\
\text { orsos/LSM/ pemerintah. }\end{array}$ & $\begin{array}{l}\text { Tokoh adat, tokoh } \\
\text { pemuda,agama, wanita,LS } \\
\text { M, kk miskin }\end{array}$ & Deep Interview \\
\hline 10 & $\begin{array}{l}\text { Keberdayaan kk miskin } \\
\text { (keberdayaan sosial, }\end{array}$ & $\begin{array}{l}\text { Keluarga miskin, kerabat, } \\
\text { tokoh masyarakat,LSM }\end{array}$ & Deep Interview \\
\hline
\end{tabular}




\begin{tabular}{|l|l|l|l|}
\hline & ekonomi, psikologis) & aparat pemerintah. & \\
\hline
\end{tabular}

\section{Analisa Data Kualitatif}

Penelitian kualitatif dilakukan tiga jalur analisis yaitu reduksi data, penyajian data dan penarikan kesimpulan. Melalui reduksi data maka dilakukan proses pemilihan, pemusatan perhatian pada penyederhanaan, pengabstrakan dan transf ormasi data dasar yang muncul dari catatancatatan tertulis di lapangan. Proses ini dilakukan secara terus-menerus selama penelitian berlangsung, bahkan sebelum data benar-benar terkumpul, sebagaimana nampak dari kerangka konseptual, permasalahan penelitian, dan pendekatan pengumpulan data yang ditetapkan (Mileset al. 1984).

\section{TEMUAN DAN PEMBAHASAN}

\section{Fenomena Kemiskinan di Aceh}

Kemiskinan merupakan suatu keadaan dimana seseorang tidak sanggup memlihara dirinya sendiri sesuai dengan taraf kehidupan kelompok dan juga tidak mampu memanfaatkan tenaga, mental, maupun fisiknya dalam kelompok tersebut. Menurut sejarah keadaan kaya dan miskin secara berdampingan tidak merupakan masalah sosial sampai saatnya pandangan berkembang dengan pesat dan timbulnya nilai-nilai sosial yang baru.

Aceh menerima pukulan yang keras dari krisis keuangan pada tahun 1997-1998, samahalnya dengan daerah-daerah lain di Indonesia, yang berakibat pada tingkat pertumbuhan yang negatif selama empat tahun berturut-turut. Setelah tahun 2001, sementara daerah-daerah lain di Indonesia telah pulih dan mulai bertumbuh, ekonomi Aceh terus mengalami penurunan. Salah satu penyebab kurangnya pemulihan adalah konflik yang berkepanjangan, selain itu terdapat banyak faktor struktural penyebab kinerja Aceh yang lemah, seperti rendahnya tingkat investasi, basis sumberdaya manusia yang relatif rendah, kesulitan prasarana karena terabaikan dan kerusakan selama konflik serta kurangnya diversifikasi ekonomi. Pertumbuhan negatif terus berlanjut sampai pada tahun 2004, sehingga menyebabkan tingkat kemiskinan naik dua kali lipat dari tingkat Nasional .

Secara umum "miskin" adalah suatu keadaan di mana seseorang tidak sanggup memlihara dirinya sendiri sesuai dengan taraf kehidupan kelompoknya, dan tak mampu memanfaatkan tenaga, mental dan pikirannya dalam kelompok tersebut. Menurut Mahatma Gandhi, 'kemiskinan adalah kekerasan dalam bentuk yang paling buruk'. Sedangkan menurut Amartya Sen, 'orang jadi miskin karena mereka tidak bisa melakukan sesuatu, bukan karena tidak memiliki sesuatu'. Maka kunci pemberantasan kemiskinan menurutnya adalah akses, yaitu akses lembaga pendidikan, kesehatan dan infrastruktur. Kemiskinan merupakan konsep multi-dimensi tentang kesejahteraan manusia yang meliputi berbagai ukuran tradisional tentang kemakmuran, seperti 
pendapatan, kesehatan, dan keamanan. Konsumsi rumah tangga dipandang oleh para ahli ekonomi sebagai sebuah rangkuman ukuran umum tentang sumberdaya rumah tangga yang tersedia dan karenanya menjadi dimensi yang lebih disukai untuk memaulai kajian tentang kemiskinan.

Kemiskinan di Aceh sedikit meningkat pasca bencana tsunami, dari 28,4 persen pada tahun 2004 mencapai 32,6 persen pada tahun 2005. Peningkatan tersebut termasuk relative kecil mengingat besarnya kerusakan dan kerugian yang disebabkan oleh tsunami dan juga mencerminkan dampak yang positif dari upaya awal rekontruksi. Tingkat kemiskinan turun pada tahun 2006 hingga mencapai 26,5 persen, lebih rendah dari tingkat kemiskinan sebelum tsunami. Hal ini menunjukkan bahwa peningkatan kemiskinan yang berkaitan dengan tsunami tidak berlansung lama dan aktivitas rekontruksi kemungkinan besar memfasilitasi penurunan tersebut. Pada tahun 2006 tingkat kemiskinan di Aceh menurun, sementara tingkat kemiskinan diwilayah lain meningkat, Kemiskinan di Aceh tetap jauh lebih tinggi dibandingkan wilayah-wilayah lain di Indonesia. Menurut Towsend kemiskinan didasari pada tingkat kebutuhan dasar, pendekatan ini memiliki dua elemen kunci, pertama ialah pendapatan yang tidak cukup untuk memenuhi kebutuhan subsistem akan pangan, papan, pakaian dan barang-barang rumah tangga tertentu, dan kedua jasa-jasa penting tertentu seperti air minum yang aman, sanitasi, transportasi umum, pelayanan kesehatan dan pendidikan. Kemiskinan alamiah (natural), yakni kemiskinan yang timbul sebagai akibat terbatasnya jumlah sumber daya atau karena tingkat perkembangan teknologi yang sangat rendah. Artinya suatu masyarakat menjadi miskin karena secara alamiah memang ada, dan bukan bahwa aka ada kelompok atau individu di dalam masyarakat tersebut lebih miskin dari yang lain.

\section{Faktor Penyebab Kemiskinan}

Kemiskinan dicirikan oleh rendahnya pendapatan dan cenderung tidak menentu setiap saat. Rendahnya pendapatan ini berujung pada sulitnya mengakses pendidikan dan kesehatan yang layak. Rendahnya pendidikan menyebabkan lemahnya daya saing rumah tangga miskin dalam memperebutkan peluang pekerjaan yang lebih layak secara ekonomi. Selain itu tingkat pendapatan yang rendah menyebabkan kemampuan untuk melakukan akumulasi modal menjadi sangat terbatas. Oleh karena itu, rumahtangga miskin tidak dapat mengakses teknologi yang mampu meningkatkan pendapatan rumah tangga mereka. Keadaan ini sangat sesuai dengan teori lingkaran kemiskinan. Akses pendapatan yang diperoleh dihabiskan sepenuhnya untuk memenuhi kebutuhan hidup rumah tangga. Peluang untuk melakukan Investasi tidak dapat dilakukan karena rendahnya tingkat pendapatan. Sebenarnya rumah tangga miskin mempunyai kesempatan untuk mengakses modal finansial melalui lembaga pengkreditan. Namun demikian, 
akses ini tidak digunakan dengan baik karena sulitnya persyaratan yang harus di penuhi. Salah satu akses untuk mendapatkan modal finansial adalah dengan memanfaatkan ikatan kekerabatan yang ada.

\section{Pertumbuhan Ekonomi yang Rendah di Aceh}

Pertumbuhan ekonomi telah diidentifikasikan sebagai salah satu pendorong utama pengurangan kemiskinan. Sebagian besar Negara yang berhasil mengurangi kemiskinan secara signifikan dalam jangka waktu yang lama berpengaruh demikian ketika ekonominya berkembang. Laju pengurangan kemiskinan akibat dari pertumbuhan ekonomi bisa sangat berbeda, tergantung pada ketidak adilan dan pola distribusi pertumbuhan . Apabila pertumbuhan memberi keuntungan terutama bagi mereka yang mampu, kemiskinan akan berkurang lebih lambat. Timmer (2007) menjelaskan panjang lebar penyebab utama dan pilihan kebijakan yang memungkinkan Idonesia untuk memperoleh manfaat dari pertumbuhan yang berpihak kepada golongan miskin untuk jangka waktu lama. Ia mengidentifikasikan adanya integrasi yang erat antara pasar tenaga kerja pedesaan dan perkotaan serta peningkatan produktivitas pertanian melalui investasi dalam prasarana pedesaan dan prasarana pertanian di antara faktor-faktor utama untuk pertumbuhan yang berpihak pada golongan miskin di Indonesia. Baik laju maupun pola-pola pertumbuhan akan menjadi penting untuk usaha pengurangan kemiskinan di Aceh .

\section{Pemberdayaan Masyarakat Relokasi}

Pemberdayaan merupakan salah satu pendekatan untuk mengatasi persoalan kemiskinan, ketidak berdayaan dan kerentanan masyarakat lemah. Ide dasar adalah untuk mewujudkan suasana kemanusiaan yang adil dan beradab. Secara lebih spesifik pemberdayaan dapat diartikan sebagai proses yang terencana dan sistematis, yang dilakukan secara berkesinambungan, baik bagi individu atau kolektif, guna mengembangkan daya potensi dan kemampuan yang terdapat dalam diri sendiri sehingga mampu melakukan transformasi sosial. Terdapat empat prinsip yang sering digunakan untuk suksesnya program pemberdayaan, yaitu kesetaraan, partisipasi, keswadayaan/kemandirian, dan keberlanjutan.

\section{Kesetaraan}

Dalam proses pemberdayaan masyarakat harus adanya kesetaraan atau kesejajaran kedudukan antara masyarakat dengan lembaga yang melakukan program-program pemberdayaan masyarakat maupun di antara laki-laki dan perempuan. Tidak Ada dominasi kedudukan di antara pihak-pihak tertentu. 


\section{Partisipasi}

Broody dan Rogers dalam Sutrisno dan Widodo 1993 mengatakan bahwa kemandirian masyarakat akan tumbuh dalam lingkungan yang banyak menawarkan pilihan sekaligus tantangan dalam mencapai kesempurnaan kepribadian. Masyarakat akan terbiasa berpikir kreatif untuk menentukan pilihan yang dianggapnya terbaik dan biasa memikul tanggung jawab atas konsekuensi yang timbul karena pilihannya . Program pemberdayaan yang dapat menstimulasikan kemandirian masyarakat adalah program yang sifatnya partisipatif, direncanakan, dilaksanakan, diawasi, dan dievaluasi oleh masyarakat. Namun untuk sampai pada tempat tersebut perlu waktu dan proses pedampingan yang melibatkan pedamping yang berkomitmen tinggi terhadap pemberdayaan masyarakat.

\section{Keswadayaan/Kemandirian}

Menurut Verhagen, 1996 Prinsip keswadayaan adalah menghargai dan mengedepankan kemampuan masyarakat daripada bantuan pihak lain. Konsep ini tidak memandang orang miskin sebagai obyek yang tidak berkemampuan (the have not), melainkan sebagai subyek yang memiliki kemampuan serba sedikit (the Have litte). Prinsip ini 'mulailah dari apa yang mereka punya', menjadi panduan untuk mengembangkan keberdayaan masyarakat. Sementara bantuan teknis harus secara terencana mengarah pada peningkatan kapasitas, sehingga pada akhirnya pengelolaannya dapat dialihkan kepada masyarakat sendiri yang telah mampu mengorganisir diri untuk menyelesaikan masalah yang dihadapinya

\section{Keberlanjutan}

Program pemberdayaan perlu dirancang untuk berkelanjutan, sekalipun pada awalnya peran pedamping lebih dominan dibanding masyarakat sendiri. Tetapi secara pelahan dan pasti, peran pedamping akan makin berkurang, bahkan akhirnya dihapus, karena masyarakat sudah mampu mengelola kegiatannya sendiri.

\section{Hasil Pembahasan}

Untuk melihat hasil penelitian yang telah penulis lakukan, maka di jelaskan pada Tabel 1 :

Tabel 1. Karakteristik Kemiskinan di Gampong Cou Kumbang dan Gampong Suak Ie Beuso

\begin{tabular}{|c|c|c|c|}
\hline \multirow{2}{*}{ No } & \multirow{2}{*}{$\begin{array}{c}\text { Aspek-Aspek } \\
\text { Terkait }\end{array}$} & Gampong Cot Kumbang & Gampong Suak Ie Beuso \\
\cline { 3 - 4 } & & & \\
\hline 1 & Kondisi & Menjadi Pengangguran & Kemiskinan masyarakat \\
\hline
\end{tabular}




\begin{tabular}{|c|c|c|c|}
\hline & $\begin{array}{l}\text { Keluarga } \\
\text { Miskin }\end{array}$ & $\begin{array}{l}\text { karena kehilangan } \\
\text { pekerjaan, yang dulunya } \\
\text { sebagai nelayan sekarang } \\
\text { sudah menjadi buruh. }\end{array}$ & $\begin{array}{l}\text { sangat terasa ketika } \\
\text { direlokasi karena } \\
\text { transfortasi masyarakat } \\
\text { harus menempuh akses } \\
\text { transportasi yang jauh } \\
\text { dari relokasi menuju } \\
\text { gampong asal untuk } \\
\text { bekerja. }\end{array}$ \\
\hline 2 & $\begin{array}{l}\text { Pola } \\
\text { penanganan } \\
\text { diberikan } \\
\text { kepada } \\
\text { Keluarga miskin } \\
\text { oleh NGO dan } \\
\text { Pemerintah }\end{array}$ & $\begin{array}{l}\text { Bantuan dari NGO Tirfan } \\
\text { berupa bidang pertanian, } \\
\text { Bantuan Nelayan dari } \\
\text { NGO CWS dan dinas } \\
\text { perikanan.Bantuan } \\
\text { peternakan lembu } \\
\text { sebanyak } 27 \text { ekor dari } \\
\text { Pemerintah Aceh Barat, } \\
\text { namun dari penduduk } \\
\text { miskin yang ada tidak } \\
\text { memperolehnya }\end{array}$ & $\begin{array}{l}\text { Lahan sawit } 97 \text { hektar } \\
\text { dibagi } 140 \mathrm{KK} \text {, karena } \\
\text { yang diberikan lahan } \\
\text { gambut menyebabkan } \\
\text { gagal panen, Begitpun } \\
\text { Bantuan nelayan dari } \\
\text { dinas perikanan hanya } \\
\text { mampu dimanfaatkan } \\
\text { sementara saja seperti } \\
\text { alat-alat penangkapan } \\
\text { ikan }\end{array}$ \\
\hline 3 & $\begin{array}{l}\text { Proses } \\
\text { pelaksanaan } \\
\text { program oleh } \\
\text { pemerintah } \\
\text { kepada } \\
\text { keluarga miskin }\end{array}$ & $\begin{array}{l}\text { Pemerintah } \\
\text { melaksanakan program } \\
\text { sesuai dengan pengajuan } \\
\text { kebutuhan dan } \\
\text { keinginan masyarakat } \\
\text { melalui proposal }\end{array}$ & $\begin{array}{l}\text { Pemerintah } \\
\text { melaksanakan program } \\
\text { sesuai dengan } \\
\text { pengajuan oleh } \\
\text { pemerintah Gampong }\end{array}$ \\
\hline 4 & $\begin{array}{l}\text { Hubungan } \\
\text { timbal balik } \\
\text { antara Keluarga } \\
\text { miskin dengan } \\
\text { keluarga yang } \\
\text { tergolong lebih } \\
\text { mampu }\end{array}$ & $\begin{array}{l}\text { Saling tolong menolong } \\
\text { antara warga miskin } \\
\text { dengan yang mampu }\end{array}$ & $\begin{array}{l}\text { Individual antara } \\
\text { keluarga lebih mampu } \\
\text { terhadap keluarga } \\
\text { miskin. Karena } \\
\text { menganggap dalam } \\
\text { status social yang tidak } \\
\text { sama. }\end{array}$ \\
\hline 5 & $\begin{array}{l}\text { Sikap } \\
\text { penanganan } \\
\text { Terhadap KK } \\
\text { miskin dalam } \\
\text { pelaksanaan } \\
\text { program } \\
\text { pemerintah }\end{array}$ & $\begin{array}{l}\text { Melibatkan masyarakat } \\
\text { melalui kelompok, jika } \\
\text { berhasi akan dibagi } \\
\text { merata }\end{array}$ & $\begin{array}{l}\text { Masyarakat miskin } \\
\text { dilibatkan aktif dalam } \\
\text { melaksanakan program } \\
\text { pemerintah. }\end{array}$ \\
\hline
\end{tabular}




\begin{tabular}{|c|c|c|c|}
\hline 6 & $\begin{array}{l}\text { Kepercayaan } \\
\text { Sosial (Trust) }\end{array}$ & $\begin{array}{l}\text { Orang miskin } \\
\text { berpendapat supaya ada } \\
\text { simpan pinjam uang dari } \\
\text { pemerintah desa. }\end{array}$ & $\begin{array}{l}\text { Masyarakat miskin } \\
\text { mengaspirasikanadany } \\
\text { a jalan pintas untuk } \\
\text { pulang ke kampong } \\
\text { asal demi kemandirian } \\
\text { ekonomi masyarakat. }\end{array}$ \\
\hline 7 & $\begin{array}{l}\text { Program } \\
\text { pemerintah } \\
\text { mengatasi } \\
\text { persoalan } \\
\text { keluarga miskin }\end{array}$ & $\begin{array}{l}\text { Program pemerintah } \\
\text { hanya skala pemberian } \\
\text { bantuan tanpa } \\
\text { penyuluhan mengenai } \\
\text { kemandirian bantuan. }\end{array}$ & $\begin{array}{l}\text { Program pemerintah } \\
\text { hanya mengenai } \\
\text { keinginan aparatur desa } \\
\text { bukannya sesuai } \\
\text { dengan kebutuhan } \mathrm{KK} \\
\text { miskin }\end{array}$ \\
\hline 9 & $\begin{array}{l}\text { Upaya lainnya } \\
\text { pemerintah } \\
\text { mengatasi } \\
\text { persoalan } \\
\text { kemiskinan }\end{array}$ & $\begin{array}{l}\text { Tidak ada Upaya } \\
\text { pemerintah tanpa } \\
\text { mengajukan proposal. }\end{array}$ & $\begin{array}{l}\text { Adanya insfrastruktur } \\
\text { bangunan jalan pintas } \\
\text { yang melintasi } \\
\text { Gampong Seuneubok } \\
\text { Teungoh dengan Suak } \\
\text { Ie Beuso. }\end{array}$ \\
\hline 10 & $\begin{array}{l}\text { Pelayanan } \\
\text { Pemerintah } \\
\text { untuk } \\
\text { penduduk } \\
\text { miskin }\end{array}$ & $\begin{array}{l}\text { Pelayanan Pemerintah } \\
\text { hanyalah lahan } 24 \text { desa } \\
\text { yang sulit untuk } \\
\text { dikembangkan } \\
\text { perekonomian, selain itu } \\
\text { bantuan dana BKPG, } \\
\text { ADG, PMPM mandiri. } \\
\text { sehingga Pemerintah } \\
\text { desa membuka simpan } \\
\text { pinjam bagi penduduk } \\
\text { Gampong sebagai modal. }\end{array}$ & $\begin{array}{l}\text { Pelayanan pemerintah } \\
\text { untuk penduduk } \\
\text { miskin diberikan } \\
\text { pelayanan berupa } \\
\text { BKPG, ADG, dan } \\
\text { PMPM mandiri. Dari } \\
\text { pelayanan tersebut ada } \\
\text { dibukanya simpan } \\
\text { pinjam dan tidak semua } \\
\text { orang meminjamnya } \\
\text { karena sesuai aturan } \\
\text { penminjamaannya. }\end{array}$ \\
\hline 11 & $\begin{array}{l}\text { Hak } \\
\text { memperoleh } \\
\text { bantuan dari } \\
\text { Pemerintah oleh } \\
\text { penduduk } \\
\text { miskin }\end{array}$ & $\begin{array}{l}\text { Manfaat kelompok } \\
\text { adalah, membagikan } \\
\text { lembu secara merata } \\
\text { kepada warga, namun } \\
\text { kelompok tersebut } \\
\text { mengabaikannya. Setiap } \\
\text { warga Gampong berhak } \\
\text { memperoleh dan } \\
\text { diizinkan untuk }\end{array}$ & $\begin{array}{lr}\text { Setiap warga } & \text { berhak } \\
\text { memperoleh } & \text { simpan } \\
\text { pinjam, akan tetapi } \\
\text { kebanyakan masyarakat } \\
\text { tidak menagambilnya } \\
\text { dikarenakan ketakutan } \\
\text { tidak } \\
\text { membanyar } \\
\text { warga } & \text { Setiap } \\
\end{array}$ \\
\hline
\end{tabular}




\begin{tabular}{|c|c|c|c|}
\hline & & $\begin{array}{l}\text { melakukan simpan } \\
\text { pinjam, namun warga } \\
\text { menyalah gunakan } \\
\text { simpan pinjam tersebut } \\
\text { untuk kebutuhan } \\
\text { konsumtif. }\end{array}$ & $\begin{array}{l}\text { memperoleh kebun } \\
\text { sawit dan bibit karet. }\end{array}$ \\
\hline 12 & $\begin{array}{l}\text { Perlakuan } \\
\text { pemerintah } \\
\text { dalam } \\
\text { memanfaatkan } \\
\text { potensi dan } \\
\text { sumber daya } \\
\text { lokal penduduk } \\
\text { miskin }\end{array}$ & $\begin{array}{lr}\text { Terjadinya } & \text { kegagalan } \\
\text { Pemerintah } & \text { dalam } \\
\text { melakukan } & \\
\text { pendampingan } & \\
\text { masyarakat } & \text { secara } \\
\text { kontinyu } & \end{array}$ & $\begin{array}{l}\text { Kurangnya kontrol } \\
\text { Pemerintah terhadap } \\
\text { bantuan yang telah } \\
\text { diberikan, sehingga } \\
\text { menimbukan kegagalan } \\
\text { pemberdayaan dalam } \\
\text { masyarakat. }\end{array}$ \\
\hline 13 & $\begin{array}{l}\text { Dampak } \\
\text { bantuan } \\
\text { Pemerintah } \\
\text { terhadap } \\
\text { kehidupan } \\
\text { orang miskin }\end{array}$ & $\begin{array}{lr}\text { Dampak } & \text { bantuan } \\
\text { pemerintah } & \text { kepada } \\
\text { penduduk } & \text { miskin } \\
\text { menjadi rebutan bagi } \\
\text { kelompok tertentu } \\
\text { karena dibagi tidak } \\
\text { merata. } \\
\text { menimbulkan Sehingga } \\
\text { ketergantungan. }\end{array}$ & $\begin{array}{lr}\text { Dampak } & \text { bantuan } \\
\text { Pemerintah } & \text { kepada } \\
\text { masyarakat, } & \text { selalu } \\
\text { menimbulkan } & \\
\text { ketergantungan } & \\
\text { masyarakat } & \text { kepada } \\
\text { Pemerintah. } & \end{array}$ \\
\hline 14 & $\begin{array}{l}\text { Hambatan } \\
\text { pemerintah } \\
\text { dalam } \\
\text { melaksanakan } \\
\text { program } \\
\text { bantuan bagi } \\
\text { penduduk } \\
\text { miskin }\end{array}$ & $\begin{array}{l}\text { Hambatan pemerintah } \\
\text { dalam melaksanakan } \\
\text { program bantuan bagi } \\
\text { penduduk miskin yaitu } \\
\text { tidak melakukan } \\
\text { pemberdayaan secara } \\
\text { berkelanjutan, tapi } \\
\text { pemberdayaan } \\
\text { dilakukan secara singkat } \\
\text { saja. }\end{array}$ & $\begin{array}{lr}\text { Lahan sawit } & \text { yang } \\
\text { diberikan tidak cocok } & \text { com } \\
\text { untuk menanam } & \text { sawit } \\
\text { karena } & \text { berair, } \\
\text { pemerintah } & \text { tidak } \\
\text { membangun } & \text { jalan } \\
\text { untuk mudahnya } \\
\text { masyarakat } \\
\text { mengeluarkan } \\
\text { pertaniaanya. }\end{array}$ \\
\hline 15 & $\begin{array}{l}\text { Menimalisirkan } \\
\text { dan mengatasi } \\
\text { angka } \\
\text { kemiskinan di } \\
\text { relokasi }\end{array}$ & $\begin{array}{l}\text { Masalah angka } \\
\text { kemiskinan di relokasi } \\
\text { sulit untuk diminimalisir } \\
\text { karena pendapatan } \\
\text { masyarakat hnya cukup } \\
\text { untu kebutuhan rumah } \\
\text { tangga dan tidak sempat } \\
\text { untuk melakukan } \\
\text { investasi. }\end{array}$ & $\begin{array}{l}\text { Masalah kemiskinan } \\
\text { sulit diatasi di } \\
\text { masyarakat relokasi, } \\
\text { karena para ibu rumah } \\
\text { tangga hanya menjadi } \\
\text { penganguran karena } \\
\text { keterbatasan sumber } \\
\text { daya alam dan sumber }\end{array}$ \\
\hline
\end{tabular}




\begin{tabular}{|c|c|c|c|}
\hline & & & daya manusia. \\
\hline 16 & $\begin{array}{l}\text { Hambatan } \\
\text { orang miskin } \\
\text { untuk } \\
\text { berkembang } \\
\text { menjadi orang } \\
\text { yang mampu }\end{array}$ & $\begin{array}{l}\text {-Hilangnya mata } \\
\text { pencaharian } \\
\text {-Bantuan yang diberikan } \\
\text { oleh pemerintah tidak } \\
\text { tepat sasaran } \\
\text {-Kurangnya trasparansi } \\
\text { dalam Gampong } \\
\text {-Jika memiliki modal } \\
\text { pinjaman, maka salah } \\
\text { digunakan oleh } \\
\text { masyarakat } \\
\text {-Ibu-ibu banyak } \\
\text { pengangguran. } \\
\text {-Ketergantungan } \\
\text { berlebihan masyarakat } \\
\text { kepada pemerintah. }\end{array}$ & $\begin{array}{l}\text {-Beralih profesi karena } \\
\text { hilangnya mata } \\
\text { pencaharian } \\
\text {-Lahan yang sempit } \\
\text {-Bantuan yang } \\
\text { diberikan kurang } \\
\text { diberdayakan } \\
\text {-para ibu-ibu banyak } \\
\text { penganguruan } \\
\text {-Pemberdayaan yang } \\
\text { masyarakat akses } \\
\text { tidak berkelanjutan } \\
\text {-Jauhnya } \\
\text { ekonomi, karena harus } \\
\text { pulang ke Gampong } \\
\text { asalnya, dan harus } \\
\text { keluar ke profesi yang } \\
\text { lain. } \\
\text {-Ketergantungan } \\
\text { masyarakat berlebihan } \\
\text { kepada Pemerintah. }\end{array}$ \\
\hline
\end{tabular}

Tabel 1. Diolah dari hasil penelitian

Dari hasil Penelitian yang dilakukan maka dapat di kekemukakan beberapa karakteristik dan fenomena kemiskinan yang terjadi di Gampong Cot Kumbang dan gampong Suak Ie Beuso ,diantaranya adalah ;

\section{Jauhnya Akses Perekonomian}

Masyarakat relokasi mengalami kemiskinan karena jauhnya akses transportasi dalam menuju tempat untuk mencari nafkah, karena sandang, pangan dan papan yang menjadi konsumtif lebih tinggi, maka membutuhkan pendapatan yang layak untuk mewujudkan kesejahteraan. Namun dari pada itu akses trasnportasi yang sangat jauh sehigga mempersulit para kaum ibu untuk bekerja. Sedangkan dilokasi relokasi tidak mempunyai lahan yang produktif. Dengan tidak ada lahan yang produktif sehingga kaum ibu banyak yang pengangguran.

Perlakuan pemerintah terhadap pemanfaatan potensi sumberdaya lokal penduduk miskin dengan tidak melakukan pemberdayaan secara efisien, sehingga kemiskinan tidak bisa dihindari dari kehidupan masyarakat relokasi, 
karena kondisi kemiskinan yang terjadi pada masyarakat relokasi saat ini merupakan kemiskinan natural atau kemiskinan yang terjadi secara alamiah. Dimana kemiskinan ini terjadi akibat kondisi tempat tinggal masyarakat yang tidak produktif, disamping lahan yang diberikan sangat sempit juga tidak memiliki potensi alam perikanan dan pertanian.

\section{Kegagalan Pemeberdayaan Masyarakat Oleh Pemerintah dan LSM}

Kegagalan pemberdayaan masyarakat menjadi suatu masalah besar bagi kehidupan masyarakat relokasi, karena pemberdayaan masyarakat secara kontinyu akan menuju masyarakat yang mandiri. Namun saat ini kehidupan masyarakat relokasi sangat sulit untuk mengembangkan diri, karena pemberdayaan yang dilakukan baik dari NGO maupun pemerintah hanya untuk menjalankan program semata, selesai program maka masa pemberdayaan berakhir. Jika pemberdayaan dilakukan terus menerus maka kemiskinan akan mampu untuk di minimalisir dikalangan masyarakat relokasi.

\section{Ketergantungan Masyarakat Yang Berlebihan Kepada Pemerintah}

Masyarakat relokasi tidak terlepas dari ketergantungan, dimana kondisi masyarakat dengan alasan lahan sempit yang diberikan oleh Pemerintah dan tidak memiliki sumber daya alam disekelilingnya sengga selalu menumpu harapan pada sifat ketergantungan diri pada Pemerintah. Sebenarnya pemerintah sudah sangat banyak memberikan bantuannya kepada masyarakat relokasi namun masyarakat tidak mengelola secara efisien. Karena masyarakat relokasi ini memanfaatkan bantuan pemerintah untuk mewujudkan kesejahteraan hidupnya, sehingga sangat sulit untuk memandirikan masyarakat relokasi untuk menjadi masyarakat yang produktif selama ketergantungan tersebut belum dilupakan dalam kehidupannya.

\section{PENUTUP}

Berdasarkan hasil wawancara dengan respoden, peneliti menemukan beberapa masalah yang menjadi kesimpulan,

1. Secara Historis, penyebab kemiskinan di Aceh selama mengalami dua periode yang sangat signifkan dalam perubahan kemiskinan diantaranya, periode masa konflik, dan periode masa bencana Tsunami.

2. Kemiskinan disebabkan besarnya pengeluaran dibandingkan pendapatan. Salah satunya Masyarakat relokasi Ketika berdomisili di wilayah pesisir kondisi ekonomi masyarakat mencapai taraf kesejahteraan karena potensi alam yang strategis dan produktif. Ketika berdomisili di relokasi tsuami menjadi ujung tombak penumpang ekonomi keluarga, yang menempuh jarak akses transportasi dalam mencari nafkah. Sedangkan perempuan hanya menjadi ibu rumah tangga yang tidak produktif karena kondisi geografis yang tidak berpotensi produktif. Bahkan ada keluarga yang tidak konsumsi 
makanan dalam sewaktu, namun dari kehidupan social saling membantu satu sama lain untuk membantu para janda tua.

3. Adapun bantuan dari Pemerintah dan NGO yang diberikan kepada masyarakat, namun tidak mewujudkan kemandirian masyarakat, karena terjadinya kegagalan pemberdayaan masyarakat oleh Pemerintah dan NGO atau LSM. Kegagalan pemberdayaan masyarakat itu terjadi karena pemberdayaan masyarakat yang dilakukan hanya bersifat sementara, dan tidak ada kontrol sosial setelah bantuan itu dikerahkan. Kemiskinan sulit diminimalisirkan dalam kehidupan masyarakat miskin selama ketergantungan masyarakat pada Pemerintah belum ditinggalkan dalam kehidupannya.

\section{REFERENSI}

Azwar, Saifudin. 2003. Sikap Manusia-Teori dan Pengukurannya. Edisi kedua Cetakan VII. Yogyakarta: Pustaka Pelajar

[BAPPEDA Aceh]. 2013. Rencana Pembangunan Jangka Menengah Aceh 2012 2017. Banda Aceh : Bappeda Aceh.

BRR NAD-NIAS. 2008. Kajian Kemiskinan Di Aceh : Dampak Konflik, Tsunami, dan Rekonstruksi Terhadap Kemiskinan Di Aceh. The Word Bank: Jakarta.

Irawan P. 2002. Logika dan Prosedur Penelitian; Pengantar Teori dan Panduan Praktis Penelitian Sosial bagi Mahasiswa dan Peneliti Muda. Jakarta: STIA-LAN Press.

Jonathan Sarwono. 2006. Analisis Jalur Untuk Riset Bisnis dengan SPSS. Yogyakarta: Penerbit Andi.

Maleong. 2007. Metodologi Penelitian Kualitatif. Bandung: PT. Remaja Rosdakarya

Pusat Data dan Informasi Kesejahteraan Sosial. 2008. Data Penyandang Masalah Kesejahteraan Sosial. Jakarta: Pusat Data dan Informasi Kesejahteraan Sosial.

Putnam, R.D. 2000. Bowling Alone: The Collepse and Revival of American Community. New York: Simon and Schuster.

Rangkuti, Freddy. 2008. Analisis SWOT Teknik Membedah Kasus Bisnis. Jakarta: Gramedia Pustaka Utama.

Sajogyo. 1991. Penanggulangan Kemiskinan; Beberapa Pokok Bahasan. Bogor : Fakultas Pertanian Institut Pertanian Bogor. 
Singarimbun S, Effendi S. 2006. Metode Penelitian Survai. Jakarta; LP3ES.

[13] Soekanto, Soerjono. 2006. Sosiologi Suatu Pengantar. Jakarta: PT. Raja grafindo Persada.

Soetrisno. R. 2001. Pemberdayaan Masyarakat dan Upaya Pembebasan Kemiskinan. Philosophy Press : Jakarta.

[Syahyuti, 2006. 30 Konsep Penting dalam Pembangunan Pedesaan dan Pertanian. PT. Bina Rena Pariwara : Jakarta Selatan.

Timmer, C.Peter. 2007. How Indonesia Connected the Poor to Rapid Ekonomik Grawth, in Word Bank, 2007, "Dellivering on the Promise of Pro Poor GrowthInsigths and Lessons From Country Experiences", diedit oleh Timothy Besley dan Loise J. Cord.

Townsend. 1993. Poverty. Dalam: Adam Kuper dan Jessica Kuper, Ensiklopedia Ilmuilmu sosial. Diterjemahkan: Haris Munandar, dkk. PT Raja Grafindo Persada: Jakarta.

Widodo, Slamet. 2011. Strategi Nafkah Berkelanjutan Bagi Rumah Tangga Miskin Di Daerah Pesisir. Program Studi Agribisnis, Fakultas Pertanian, Universitas Trunojoyo: Bangkalan Indonesia.

World Bank. 2007a. Investing in Indonesia's Education : Allocation, Equity, and Efficiency of Public 